\title{
Cost-Effective and Eco-Friendly Methods for Lake Water- Purification
}

\section{Dr. Savita Dixit and Shlok Dixit}

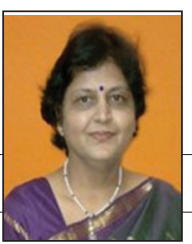

Savita Dixit

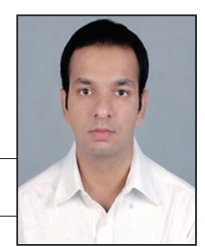

Shlok Dixit

Abstract: Lakes and reservoirs are very important property for people's life, industrial activities and so on. They provide various benefits to us, such as securing water resources for drinking, agriculture and industrial use, fishery resource, flood control functions and ecosystem integrities. However, because of the closed nature of lakes' water system, pollution tends to accumulate therein, once water is polluted, it is difficult to improve the water quality. In Addition, the situation is that a remarkable improving tendency of the water quality of lakes is not seen due to the increase of the pollutant load by the economic change and the increase of the Industrialization and population as well as the change in the lake environment.

Bhopal city popularly known as the city of lakes, have more than eighteen water bodies. Out of eighteen water bodies, few are source of drinking water after preliminary treatment. Rest of the water bodies serves secondary purposes like irrigation, fisheries and recreational activities etc. These two lakes are Shahpura Lake and Lower Lake. Shahpura Lake is situated in new Bhopal city where as Lower Lake is situated in old city. Both are eutrophic and sewage fed lake.

Keywords: Water Quality, Treatment, lake, physico-chemical, aeration unit, macrophytes, sewage, Bhopal, India

\section{Introduction}

T akes and reservoirs are very important property for Leople's lives, industrial activities and so on. They provide various benefits to us, such as securing water resources for drinking, agriculture and industrial use, fishery resource, flood control functions and ecosystem integrities. However, because of the closed nature of lake' water system, pollution tends to accumulate therein. Once water is polluted, it is difficult to improve the water quality. In Addition, the situation is such that a tendency of remarkable improvment in the water quality of the lakes is not seen due to the increase in the pollutant load due to the economic change and the increase in the population as well as the change in the lake environment etc.

The study is an attempt of analysis of the water quality of both the lakes in the year 2007 and observes the change in lake water chemistry by natural and cost effective methods.

\section{(a) Macrophytes (b) Aeration units}

Heavy matels are the factors that contribute to environmental pollutation. Firstly they cannot be destroyed through biological degradation as in the case with most organic pollutants and secondly metals tend to accumulate in the environment especially with bottom sediments of rivers and lakes by association with organic and inorganic matter. In aquatic environment metals can be termed as "Conservative pollutants", which when added to the aquatic environment remain there forever and cannot be broken down to harmless substances by bacterial action like many organic pollutants. Apart from it, a large number of heavy metals is contributed by corrosion of metal pipes. Runoff waters from surroundings during rainy season are rich in heavy metals like $\mathrm{Cu}, \mathrm{Cr}, \mathrm{Zn}, \mathrm{Pb}$ etc. Lead from automobiles released into atmosphere find its way in the run off waters. The discharge of heavy metals in the environment has many obvious impacts on aquatic systems. There may be an increase in residue levels in water, sediments and biota, decreased productivity and increase in exposure of humans to harmful substances, (Moore 1984).

Present study is based on the water purification through macrophyte and aerators in Shahpura Lake and Lower Lake of Bhopal city.

\section{Macrophytic Technique (Root Zone Technique)}

Macrophytes are commonly observed features in aquatic eco-system. Macrophytes have capacity to assimilate large quantities of nutrients and heavy metals. They are also known as bio-filters. It is generally observed that eutrophic water bodies have dense population of various aquatic macrophytes. Some of the species of macrophytes play vital role in the assimilation of nutrient through roots.

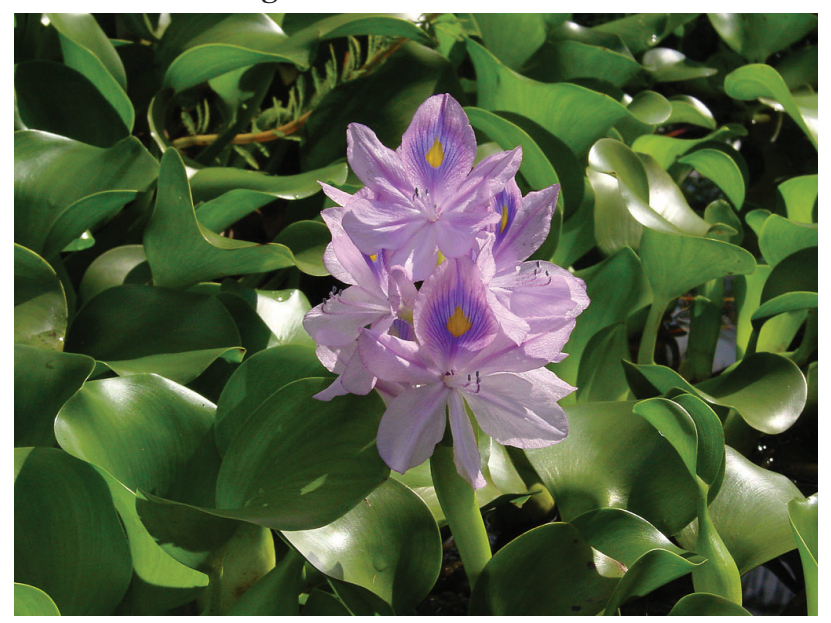

Figure.1 - Eichhornia crassipes (Water Hyacinth)

Eichhornia crassipes (Water Hyacinth) is one of the species of macrophytes. The roots of Eichhornia crassipes acts like a living substrate for attached 
microorganisms, which then provide a significant degree of treatment for their metabolism (U.S.EPA, 1988). It is a free floating, abundantly available and fast growing aquatic macrophyte. Now a days some recent research activities also reported that the dry material of E. crassipes also helpful in adsorbing heavy materials.

\section{Aeration}

Initially the aerators were installed for beautification but latter it was realized that it could be means for water purification as it improve the oxygen level in the water and also facilitate the microbial activities.

The aeration process is also used to remove volatile substances and gases present in water and wastewater and to improve the dissolved oxygen (DO) content in the water and wastewater (Rao and Kumar, 2007). Aeration is the most important and indispensable operation unit for the treatment of wastewater (Chen et. al., 2003); (Boyle, 2002); (Reardon, 1995). It improves water quality by increasing dissolved oxygen levels in the water especially where oxygen is needed i.e. at the bottom. Aeration through aerators needs no chemicals for purification, aeration is most effective in warm climate. (Savita etal et. al., 2005) reported that the artificial aeration cum ozonizer unit contribute to the improvement of water quality in an eco-friendly way. Use of aerators is often safe and sound form of pollution removal. It is one of the effective methods for restoration of urban lakes. Aerators are helpful in :

- Higher densities of fish

- Check winter kills caused by low oxygen levels

- Improve overall water quality

- Speed up the rate of organic decomposition

- Reduce the amount of phosphorus, which would otherwise be available for plant growth

- Thermally and chemically, deteriorate the water.

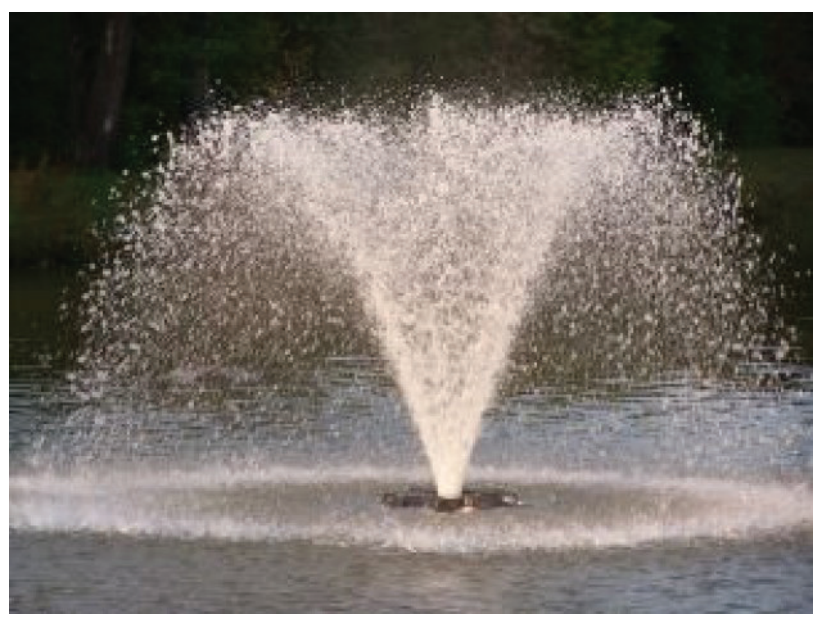

Fig.ure2 - Aerator Unit

\section{Study Area}

\section{Lower lake}

Lower Lake is situated in a thickly populated area of the old city of Bhopal. Major portion of the shoreline of this man-made lake is natural except for north eastern part and western corner, which are dammed. The western dam separates the Lower Lake from the other lake called Upper Lake. The lake receives sewage and runoff from the catchment area through number of inlets.

\section{Shahpura Lake}

Shahpura Lake is also known as third lake of the city. It is totally sewage fed and a highly eutrophic lake. It is a man made water body and situated in southern part of the city Bhopal. It was constructed in 1974-75 under Betwa irrigation scheme. The lake has a catchment area of $8.29 \mathrm{sq} . \mathrm{km}$. and a submergence area of $0.96 \mathrm{sq}$. $\mathrm{km}$. The lake is surrounded by residential areas from southern side, western side and eastern side. Ekant Park is in northern side of the lake. There is one major inlet passing through Ekant park receives residential waste from Panchsheel Nagar. Irrigational use of reservoir water has become secondary but fisheries and recreational activities are primary these days.

The water quality is deteriorating day by day due to untreated sewage inflow, sanitation, cattle population, weeds encroachment, deforestation etc. The situation of lake is alarming and it is the right time to think about the conservation and management of the lake.

\begin{tabular}{|l|l|l|}
\hline $\begin{array}{l}\text { Salient Features of } \\
\text { the Lake }\end{array}$ & Lower Lake & $\begin{array}{l}\text { Shahpura } \\
\text { Lake }\end{array}$ \\
\hline The year of construction & 1794 & 1974 \\
\hline Type of dam & Earthen dam & Earthen dam \\
\hline Longitude & $77024^{\prime}-77026^{\prime} \mathrm{E}$ & $77025 / 30 / /$ \\
\hline Latitude & $23014^{\prime} 30^{\prime \prime}-23015^{\prime} 30^{\prime \prime} \mathrm{N}$ & $\begin{array}{l}23012 / 0 / / \\
\text { East }\end{array}$ \\
\hline Catchment area & $9.6 \mathrm{~km}^{2}$ & $8.29 \mathrm{Km}^{2}$ \\
\hline $\begin{array}{l}\text { Submergence area at } \\
\text { FTL }\end{array}$ & $1.287 \mathrm{~km}^{2}$ & $0.96 \mathrm{~km}^{2}$ \\
\hline Storage Capacity & $3.5 \mathrm{M} . c u m$ & $2.29 \mathrm{M} . \mathrm{cum}$ \\
\hline Sewage water inflow & $36627 \mathrm{cum} /$ day & - \\
\hline Main use of water & Washing, Boating & $\begin{array}{l}\text { Fisheries, } \\
\text { recreation, } \\
\text { automobile } \\
\text { washing }\end{array}$ \\
\hline Shore line length & $6.15 \mathrm{~km}$ & - \\
\hline Maximum depth & $9.4 \mathrm{~m}$ & - \\
\hline $\begin{array}{l}\text { Elevation of waste water } \\
\text { weir }\end{array}$ & $99.88 \mathrm{~m}$ above MSL & - \\
\hline Maximum water level & $499.88 \mathrm{~m}$ above MSL & - \\
\hline
\end{tabular}

Table 1: Salient Features of Study Area

\section{Materials and Methods}

The water samples were collected by standard methods of sample collection as prescribed in APHA 1998 for both the lakes.

pH: The $\mathrm{pH}$ of water body was determined using digital $\mathrm{pH}$ meter (APHA, 1998). The $\mathrm{pH}$ indicates the acidity or alkalinity of water. $\mathrm{pH}$ is an important parameter because it controls the state of various nutrients including nitrate, phosphate, dissolved oxygen etc, Goldman, (C. et al. 1983). 
DO: The water sample was collected and Dissolved Oxygen was fixed instantly on the spot and analyzed immediately as per the Wrinkler's method with Azide modification (APHA, 1998. The dissolved oxygen has a great importance in an aquatic eco-system. It is considered as the pollution indicator parameters. It reflects the biological activity taking place in a water body and also determines the biological changes, which is due to aerobic and anaerobic organisms. A common observation was that the bottom oxygen demand is low as compare to surface water.

BOD: The water sample was collected and was incubated at $200 \mathrm{C}$ for 5 days (NEERI Manual). The BOD5 is that fraction of dissolved organic matter, which is degraded and easily assimilated by bacterial population. It is the amount of dissolved oxygen required in $\mathrm{mg} / \mathrm{l}$ for stabilizing the biodegradable organic matter by microorganisms of the sample under aerobic conditions in a stated time. It is a good index of the organic pollution and helps in deciding suitability of water for human consumption.

COD: COD was determined by potassium dichromate open reflex method (NEERI Manual).

Heavy Metals: Heavy metals are determined by Atomic Absorption Spectrophotometer (APHA, 1998).

Nitrate and Phosphate content was determined as per standard method (APHA, 1998).

Nitrate is the important pollution indicator parameter. It is considered as important plant nutrient. In aquatic ecosystem, inorganic phosphate as soluble orthophosphate plays a dynamic role. The orthophosphates are readily taken up by the plants.

Table 2 below summarizes the comparative description of the two methods of water purification in terms of five key water quality parameters.

\section{Result and Discussion}

\begin{tabular}{|c|c|c|c|}
\hline $\begin{array}{l}\text { S. } \\
\text { No. }\end{array}$ & Parameter & $\begin{array}{l}\text { Aeration (\% } \\
\text { variation) }\end{array}$ & $\begin{array}{l}\text { Macrophytes (\% } \\
\text { variation) }\end{array}$ \\
\hline 1 & $\mathrm{DO}$ & 12.5 (up gradation) & 10.00 (Upgrade) \\
\hline 2 & $\mathrm{BDO}_{5}$ & 20.0 (reduction) & 10.34 (reduction) \\
\hline 3 & $\mathrm{CDO}$ & 33.33 (reduction) & 25.67 (reduction) \\
\hline 4 & Nitrate & 50.0 (reduction) & 40.15 (reduction) \\
\hline 5 & Phosphate & 1.85 (reduction) & 49.48 (reduction) \\
\hline
\end{tabular}

Table No. 2: Comparison between Aeration and Macrophytes in terms of five parameters

Nitrogen and Phosphorus are considered the most important among nutrients responsible for eutrophication of lake. The results show that nutrient load in both the lakes are very high and hyper eutrophic conditions are observed in Shahpura Lake as well as in Lower Lake of Bhopal.

The present study revealed that, the aeration units contribute to the improvement of water quality in an eco-friendly way. Installation of aeration units improves water quality by increasing DO levels, consequently leading to the reduction of $\mathrm{BOD}$ and $\mathrm{COD}$ levels. Therefore, the present study indicates that the aeration units are very effective in improving water quality of the lake and directly promotes tourist activity in and around Lower Lake.

Eichhornea Crassipes is efficient in reducing BOD, COD, TSS, Nitrate, and Phosphate. It reduces quantities of suspended particles, algae, dissolved impurities, nitrogen, phosphorus and other nutrients, turbidity, organic carbon etc The technology is cost effective, maintenance free, self-sustained and eco-friendly.

Therefore, the present study indicates the quality characteristics of lakes and impact assessment of aeration units, which are more effective in improving the water quality of a degraded water body.

Following recommendation for improving the water quality:

Aeration

- Number of Aeration units may be installed keeping in mind the effective area to be covered.

- Tourist activities may be promoted in a controlled way.

- Refuses and other waste material may not be thrown inside the lake i.e. proper arrangement of solid waste management must be considered while promoting tourist activities.

Savita Dixit, MPhil, PhD is a Professor of Chemistry in MANIT, National Institute of Technology at Bhopal, India, and has more than 27 years of teaching experience at graduate and post graduate levels in Indian universities. She is actively involved in research activities in environmental sciences. She has also guided $15 \mathrm{PhD}$ and $6 \mathrm{M}$. Tech. candidates towards their degrees and published more than 100 research papers in reputed journal and proceedings. She has also applied for 6 patents in her field. She is actively involved in research activities in Environmental Sciences, Polymer Composites,Natural products and Biofuels.

Corresponding address: savitadixit1@yahoo.com

Shlok Dixit, B Tech, MBA is a project fellow and has actively involved in various areas of research and has presented 7 papers and various international and national conferences in areas of Electronics, Information Technology and Environmental management.

\section{Email : shlok.dixit@gmail.com}

\section{Reference}

APHA 1998. Standard methods for examination of water and waste water, American Public Health Association, Washington, D.C., 19th Edition. 
Boyel, 2002; A Brief History of Aeration of Wastewater. Environmental and Water Resources History. 126, 2.

Chen et. al., 2003 Chen, J.H., Hsu, Y.C., Chen, Y.F., Lin, C.C., 2003. Application of gas inducing reactor to obtain high oxygen dissolution in aeration process. Water Res. 37, 2919-2928.

Goldman, C. et al. (1983). Goldman, C; \& Horne, A. Limnology, Mc Graw-Hill Book co. London, pp.464.

Moore, J.W. and Ramamoorthy, S., 1984. Heavy Metal in natural waters : Applied Monitoring and Impact Assessment, Springer -Verlag; New York, 28,246

Neeri Manual Reardon, 1995; Turning down the power. Civil Eng.65 (8), 54-56.
Okeola FO, Odebunmi EO (2010) . Freundlich and Langmuir Isotherms Parameters for Adsorption of Methylene Blue by Activated Carbon Derived from Agro wastes.

Rao and Kumar, 2007; The use of circular surface aerators in wastewater treatment tanks. J Chem. Technol. Bio technol. 82, 101-107.

Savita Dixit, Neelam Verma, Suchi Tiwari \& Avinash Bajpai, "The Effect of aeration units on water quality in Upper lake, Bhopal, India”, Electronic Green Journal, University of Idaho, Masco, Issue 22, Winter 2005, pp 1-5.

USEPA-1988 Design manual - Constructed Wetland and Aquatic Systems for Municipal Wastewater Treatment. U.S. Environmental Protection Agency Report no. EPA/625/1-88/022.Offce of Research and Development, Cincinnati, $\mathrm{OH}, 83$. .).

\section{CALENDER OF EVENTS - ENVIRONMENT AND HYDROPOWER}

16-20 March 2015 The process of Social Impact Assessment, Location: Trondheim, Norway, Application Deadline: February 30, 2015, URL: www. ich.no

1-6 June 2015, Dam Safety Inspection, Location: Trondheim, Norway, Application Deadline: 25 April 2015, URL: www.ich.no

17 August - 3 September 2015, Management of
Environmental and Social Aspects of Hydropower Development, Location: Trondheim, Norway, Application Deadline: 8 May 2015, URL: www.ich.no 19-23 October 2015, Meeting the challenges of Financing Hydropower Projects, Location: Trondheim, Norway, Application Deadline: 7 August 2015, URL: www.ich. no 